\title{
Mengadvokasi Ketidaksetaraan Gender (Peran Negara dan Hegemoni Budaya Patriarki): Study pada Rifka Annisa Woman Crisis Centre (WCC) Yogyakarta
}

\author{
Arief Hidayat $^{1}$ \& Adi Chandra Kumala ${ }^{2}$
}

\begin{abstract}
Abstrak
Artikel ini mengelaborasi advokasi ketidaksetaraan gender yang dilakukan oleh lembaga swadaya masyarakat Riska Annisa. Ketidaksetaraan tersebut tentang adanya perilaku diskriminasi negara dalam proses menangani persoalan domestik dalam keluarga, yang sudah menjadi urusan publik. Salah satunya adalah terkait isu penanganan perilaku kekerasan yang diterima kaum perempuan, urusan penyembuhan trauma bagi perempuan yang mendapatkan kekerasan, penyediaan rumah aman sampai pada advokasi dalam bentuk bantuan hukum. Persoalan yang semula diambil alih oleh negara secara yuridis, namun dalam pelaksanaannya tidak sesuai, bahkan luput dari perhatian negara. Padahal dalam konsep civil rights, seluruh warga negara mendapatkan pelayanan yang sama tanpa membedakan ras, agama, jenis kelamin, dan sebagainya. Pola diskriminasi yang berkelindan dengan ketiadaan pemihakan negara menjadi pokok persoalan yang sulit untuk diatasi. Diperlukan dukungan berbagai pihak, khususnya organ civil society sebagai motor penggerakyang mengatasi persoalan ini sehingga tidak berlarut dalam sengkarut yang tidak berujung. Secara praktis, tujuan riset ini mencakup bahasan mengenai minimnya peran negara dalam isu ketidaksetaraan gender, khususnya ketidakberdayaan perempuan dalam budaya patriarki, serta upaya yang dilakukan oleh Rifka Annisa dalam mengadvokasi

1 Penulis adalah alumni Magister Departemen Politik dan Pemerintahan, FISIPOL UGM Tahun 2020, bekerja sebagai Dosen Tidak Tetap pada Jurusan Ilmu Politik, FISIP Universitas Bangka Belitung 2020-sekarang.

2 Penulis adalah Mahasiswa Akhir Magister Departemen Politik dan Pemerintahan FISIPOL UGM, saat ini sedang menyelesaikan Tesis.
\end{abstract}


ketidaksetaraan gender tersebut. Riset ini dilakukan dengan menggunakan jenis penelitian kualitatif dengan analisis deskriptif dan untuk mempertajam kajiannya ditopang dengan kajian pustaka yang relevan. Hasil dari riset membuktikan bahwa stereotip gender terhadap perempuan masih menjadi bagian domestifikasi bagi sebagian besar masyarakat. Minimnya peran negara tercermin dari tidak opersionalnya perlindungan hukum bagi perempuan. Belum ada kerja-kerja teknis yang dilakukan oleh aparat negara. Menindaklanjuti hal ini, Rifka Annnisa bergerak untuk memberikan berbagai jenis bantuan mulai dari pendampingan, konsultasi, pemeriksaan psikologi sampai pada bantuan hukum. Implikasi dari adanya aksi Rifka Annisa membuka aras baru dalam persoalan patriarki yang dulu menjadi ranah domestik, kemudian bergeser ke ranah publik dengan perlakuan yang lebih seimbang.

Kata kunci: Gender; Patriarki; Hegemoni; Peran Negara 


\section{PENDAHULUAN}

Tulisan ini mengangkat topik mengenai advokasi ketidaksetaraan gender dalam kondisi minimnya peran negara dan hegemoni budaya patriarki. Ketidaksetaraan gender telah lama menjadi arus utama perbincangan dalam salah satu pemenuhan hak kewarganegaraan. Salah satu yang menjadi sorotan adalah bagaimana posisi perempuan yang lemah selalu menjadi korban atas dasar budaya patriaki atau kepercayaan agama tertentu. Walaupun di Indonesia telah berdiri Komisi Nasional Anti Kekerasan terhadap Perempuan pada tanggal 9 Oktober 1998 (www.komnasperempuan.go.id), tetapi dalam praktik politik di Indonesia, isu ketidaksetaraan gender kerap kali menjadi persoalan yang terlupakan. Persoalan ini tercermin dari riset yang dilakukan oleh UGM dan Universitas Oslo melalui program Power, Welfare, and Democracy (PWD) yang mendapati bahwa dalam praktik politik di Indonesia, lebih mementingkan isu kesejahteraan (Paskarina et.al., 2015). Upaya untuk memberikan porsi yang layak dalam isu gender dalam aras yang lebih luas sering kali terkendala karena tertutup isu lain yang dianggap lebih penting oleh para pemangku kebijakan. Kondisi ini menempatkan kaum perempuan sebagai objek yang berkelindan dengan ketidakberdayaan. 
Kurangnya respons negara dalam isu-isu seperti kekerasan terhadap perempuan, pelecehan seksual, perdagangan orang (human trafficking), sampai pada persoalan hukum membuat persoalan ini seolah terpinggirkan. Bukti dari tidak adanya pemihakan kebijakan negara, misalnya adalah adanya penerapan aturan tanpa penegakan hukum, penyediaan perangkat tidak dibarengi dengan operator teknis, sampai pada minimnya pos untuk membantu persoalan hukum, dengan memberikan bantuan hukum pada perempuan yang mengalami diskriminasi gender, khususnya dalam bentuk kekerasan.

Secara historis, diskriminasi gender dalam bentuk kekerasan terhadap perempuan memiliki rentang waktu yang sangat panjang. Kekerasan itu, mulanya muncul dari adanya gender yang diyakini masyarakat, yaitu pembagian peran antara laki-laki dan perempuan yang dikonstruksi secara sosial dan kultural oleh masyarakat, yang kemudian melahirkan keyakinan adanya sifat feminitas (perempuan itu lembut, lemah, emosional) (Amalia, 2011). Pola yang terulang sejak gender merupakan perbedaan yang bukan biologis dan bukan kodrat dari Tuhan namun sebuah perbedaan prilaku yang dikonstruksi secara sosial, sedangkan jenis kelamin adalah perbedaan secara biologis dan 
kodrat dari Tuhan (Fakih, 2006). Konstruksi sosial dalam konteks gender ini sering disalah artikan sebagai pembedaan berdasarkan jenis kelamin. Dari adanya pembedaan ini muncul kemudian stereotip yang membagi ruang, pekerjaan, bidang yang bersifat seksis. Pola itu terus-menerus hidup dan terwariskan sepanjang perjalanan hidup dan terkonstruksi semakin kuat dalam masyarakat.

Upaya mengurai bagaimana minimnya peran negara dalam isu ketidaksetaraan gender, terkhusus ketidakberdayaan perempuan dalam budaya patriarki membutuhkan jalan panjang. Kepedulian yang muncul dari civil society sebenarnya adalah bentuk gagalnya negara dalam memberikan jaminan hak asasi warganya. Bentuk formal dari kegagalan itu tercermin dari rendahnya minat negara dalam mengatasi akar persoalan ketidakadilan gender dengan tetap meletakkannya sebagai ranah domestik, tidak dapat disentuh negara. Padahal secara kebijakan, persoalan gender, termasuk persoalan turunannya akan menjadi serius tanpa dibarengi dengan pembelaan sepadan dan seimbang dari negara. Dengan segala sumber daya yang dimiliki negara dan kewenangannya, maka sejatinya persoalan ini dapat tuntas sesuai harapan. Fakta yang menyajikan adanya ketidaksamaan antara kebijakan 
dan operasional, tidak boleh hanya dipandang sebagai persoalan teknis, namun patut diduga sebagai cerminan keengganan negara hadir dalam persoalan ini.

Melalui kerja Rifka Annisa-Yogyakarta dalam mengadvokasi para perempuan yang terdiskriminasi secara gender, kiranya mampu membuka mata bahwa upaya penghapusan diskriminasi gender (misalnya, aspek kekerasan) merupakan sebuah perjalanan panjang (www.rifka-annisa.org/2013). Rifka Annisa, sebagaimana organisasi masyarakat sipil telah menjalankan peran dan fungsinya sejak berdiri pada tahun 1993. Sebagai aktor dalam mengupayakan agenda perlindungan bagi perempuan, secara faktual telah berhasil menjalankan program pelayanan bagi korban, termasuk dalam menguatkan dan mengembangkan sistem layanan terpadu. Prinsip self determination atau hak mengambil keputusan secara penuh oleh korban yang dianut oleh Rifka Annisa dalam pendampingan korban pun diakui merupakan satu modal pemberdayaan bagi korban (survivor) yang didampingi (Laporan Rifka Annisa, 2003). Sebagai organisasi masyarakat sipil, Rifka Annisa dalam term-nya mempunyai ideologi yang membawa mereka pada garis pergerakan dan normatifnya perubahan sosial dalam masyarakat 
menuju satu perwujudan konkrit yang akan membawa sampai ke garis finish.

Pengalaman Rifka Annisa dalam persoalan gender menyentuh banyak aspek yang sering terjadi, khususnya kekerasan, pelecehan seksual, kekerasan dalam keluarga yang melibatkan anak-anak, trafficking, dan lain-lain. Sejak tahun 2012 hingga 2017, Rifka Annisa telah mengadvokasi sebanyak 1.827 kasus. Kasus terbanyak adalah mengenai kekerasan terhadap istri sebanyak 1.325 kasus (73\%), perkosaan 198 kasus (11\%), kekerasan dalam pacaran 140 kasus (8\%), pelecehan seksual 77 kasus (4 \%), kekerasan dalam keluarga 60 kasus (3\%), dan lain-lain 27 kasus (1\%) (www.rifkaannisa.org/2018).

Kekerasan terhadap istri merupakan kasus yang mendominasi dibandingkan dengan kasus lainnya, yaitu 73\%. Angka itu dianggap sebagai puncak gunung es, yang jika ditelusuri lebih dalam akan mendapatkan angka yang jauh lebih besar dibandingkan yang tercatat, dilaporkan, serta mendapat advokasi. Peliknya persoalan ini membuat aras kepentingan penyelesaian persoalan diskriminasi gender dalam bentuk kekerasan sulit untuk dihentikan. Gerakan yang dilakukan oleh Rifka Annisa hanya sedkit cara untuk mengatasi kebuntuan yang ada tersebut. Oleh karena itu, artikel ini berupaya 
memahami peran yang dimainkan oleh Rifka Annisa dalam mengadvokasi ketidaksetaraan gender yang terjadi dalam konteks lemahnya peran negara mengenai perlindungan ketidaksetaraan gender dalam isu yang lebih aktual.

Penelitian ini berusaha memahami advokasi Rifka Annisa WCC dan peran negara dalam ketidaksetaraan gender dengan menggunakan pendekatan kualitatif, analisis deskriptif. Jenis penelitian kualitatif deskriptif menampilkan data apa adanya tanpa proses manipulasi atau perlakuan lain. Bungin mendefinisikan penelitian kualitatif sebagai penelitian yang bertujuan untuk menggambarkan, meringkaskan berbagai kondisi, berbagai situasi, atau berbagai fenomena realitas sosial yang ada di masyarakat yang menjadi objek penelitian, yang berupaya menarik realitas sosial itu ke permukaan sebagai suatu ciri, karakter, sifat, model, tanda, atau gambaran tentang kondisi, situasi atau pun fenomena tertentu (Bungin, 2007). Tujuan analisis deskriptif ini menghasilkan gambaran akurat tentang sebuah kelompok, mengambarkan mekanisme proses atau hubungan, memberikan gambaran lengkap, baik dalam bentuk verbal atau numerikal, menyajikan informasi dasar atas suatu hubungan, menciptakan seperangkat kategori, dan mengklasifikasikan subjek penelitian 
(Nazir, 2009). Pengumpulan data melalui wawancara dengan aktivis Rifka Annisa WCC, penggunaan bahanbahan dokumen seperti buku, artikel, jurnal, laporan, dan sumber daya lainnya. Lokasi penelitian ini di kota Yogyakarta. Data dalam artikel ini merupakan rangkaian interaktif dengan para pegiat Rifka Annisa, observasi partisipan, dan penelusuran terhadap kegiatan yang dilakukan oleh Rifka Annisa, serta sumber-sumber kepustakaan yang mendukung sepanjang medio JuliDesember 2018.

\section{DOMESTIFIKASI KEKERASAN PEREMPUAN}

Kekerasan terhadap perempuan adalah fakta yang tidak terbantahkan di negara ini dan setiap tahunnya mengalami peningkatan. Dalam catatan Komnas Perempuan pada tahun 2003, jumlah kasus yang dilaporkan sebanyak 7.787 kasus, tahun 2004 sebanyak 14.020 kasus, tahun 2005 sebanyak 20.391 kasus, dan tahun 2006 sebanyak 22.512 kasus (Komnas Perempuan, 2018). Sementara dalam konteks wilayah Yogyakarta, data yang dihimpun Rifka Annisa menunjukkan adanya tren yang cukup signifikan, meskipun instrumen hukum 
sudah disahkan sebagai jawaban atas persoalan gender dan spesifiknya kekerasan.

Pemerintah Daerah Istimewa Yogyakarta telah menerbitkan Peraturan Daerah Nomor 3 Tahun 2012 tentang Perlindungan Perempuan dan Anak Korban kekerasan. Dalam Pasal 4 Perda ini disebutkan bahwa ruang lingkup perlindungan terhadap korban meliputi upaya pencegahan, pelayanan, dan pemberdayaan terhadap korban kekerasan di daerah. Selain itu, dalam Pasal 5 disebutkan bahwa bentuk-bentuk kekerasan, antara lain (1) kekerasan fisik, (2) kekerasan psikis, (3) kekerasan seksual, (4) penelantaran, (5) eksploitasi, dan/atau (6) kekerasan lainnya. Meskipun Perda ini telah di-Undang-kan pada tanggal 14 Mei 2012 dalam Lembaran Negara Nomor 3 Tahun 2012, namun kekerasan masih terjadi, bahkan dengan frekuensi yang semakin meningkat (lihat tabel 1).

\section{Tabel 1. Jumlah Kasus Kekerasan terhadap Perempuan yang Ditangani Rifka Annisadi Daerah Istimewa Yogyakata}

\begin{tabular}{|l|c|c|c|c|c|c|}
\hline \multirow{2}{*}{$\begin{array}{c}\text { Kategori Kasus di Yogya- } \\
\text { karta }\end{array}$} & \multicolumn{6}{|c|}{ Tahun } \\
\cline { 2 - 7 } & $\mathbf{2 0 1 2}$ & $\mathbf{2 0 1 3}$ & $\mathbf{2 0 1 4}$ & $\mathbf{2 0 1 5}$ & $\mathbf{2 0 1 6}$ & $\mathbf{2 0 1 7}$ \\
\hline Kekerasan terhadap Istri & 228 & 254 & 180 & 231 & 216 & 216 \\
\hline Kekerasan dalam Pacaran & 27 & 14 & 21 & 33 & 32 & 13 \\
\hline
\end{tabular}




\begin{tabular}{|l|c|c|c|c|c|c|}
\hline Perkosaan & 29 & 44 & 31 & 37 & 27 & 30 \\
\hline Pelecehan Seksual & 8 & 11 & 15 & 16 & 12 & 15 \\
\hline Kekerasan dalam Keluarga & 11 & 2 & 5 & 5 & 21 & 16 \\
\hline Trafficking & 0 & 1 & - & - & 6 & 0 \\
\hline Lain-lain & - & - & - & - & 11 & 9 \\
\hline Total & 303 & 326 & 252 & 322 & 325 & 299 \\
\hline
\end{tabular}

Sumber: Laporan Rifka Annisa, 2018

Selain jumlah yang tinggi, hal yang paling menyedihkan dari tindak kekerasan terhadap perempuan adalah menyangkut pelaku dan lokus kekerasan yang terjadi. Data Komnas Perempuan menunjukkan pelaku tindakan kekerasan terbanyak adalah orangorang terdekat korban, seperti ayah, suami, paman, atau pacar korban, artinya kekerasan dalam rumah tangga (KDRT) merupakan tindak kekerasan yang paling banyak dilaporkan. Dari segi bentuk, kekerasan terhadap perempuan tidak hanya secara fisik, tetapi juga mengalami kekerasan psikis dan seksual (Komnas Perempuan, 2018). Terhadap berbagai kekerasan yang dialami perempuan, aspek yang menjadi perhatian terpenting adalah bagaimana memulihkan perempuan yang menjadi korban kekerasan. Proses pemulihan bagi perempuan korban kekerasan bukanlah proses mudah. Terlebih lagi bagi perempuan yang mengalami kekerasan seksual, itu membutuhkan waktu yang cukup panjang 
untuk memulihkannya. Pemulihan korban kekerasan tidak saja mempertimbangkan aspek-aspek fisik, tetapi juga perlu melihat aspek psikis korban.

Setidaknya, adatigakebutuhan utamabagi perempuan yang menjadi korban kekerasan, yaitu (1) kebutuhan akan layanan medis, (2) kebutuhan akan layanan hukum, dan (3) kebutuhan akan layanan psikososial (Komnas Perempuan, 2018). Dalam konteks pemulihan korban, ketiga kebutuhan ini membutuhkan waktu yang cukup panjang dan tidak mudah untuk menjalaninya. Kegagalan dalam satu proses akan berdampak pada kegagalan proses pemulihan secara keseluruhan, karena dalam proses ini kondisi perempuan menjadi sangat rentan. Dalam konteks itu, maka diperlukan advokasi yang lebih kompleks dan mendalam supaya membantu pemulihan korban kekerasan (Komnas Perempuan, 2018).

Tantangan dalam persoalan gender ini tidak mudah diatasi tanpa keterlibatan banyak pihak. Salah satu pihak yang dianggap dekat dengan jejaring kekerasan ini adalah peran pasangan yang kurang mendapat perhatian yang tidak begitu banyak. Oleh karena itu, sinergi antarkomponen, khususnya pasangan dari perempuan, sebenarnya harus mendapatkan porsi yang besar. Persoalan gender dan kekerasan sepenuhnya 
bukan hanya persoalan budaya partiarki yang muncul dalam masyarakat, tetapi juga ketidakmampuan perempuan dalam mengakses informasi dan juga advokasi. Ketidaktahuan inilah yang menyebabkan perempuan rentan akan tindak kekerasan karena secara teknis dan substantif, mereka tidak tahu kepada siapa hendak membela diri dan meminta perlindungan. Kekerasan yang cenderung didomestifikasi inilah yang menyebabkan pangkal lahirnya patriarki skala kecil dalam rumah tangga. Jika persoalan gender ini terusmenerus didomestifikasi, maka gender secara substansi tidak akan mendapat perhatian dari negara.

Di samping masih lemahnya perempuan dalam mengakses advokasi bagi persoalan kekerasan yang melandanya. Persoalan lain muncul adalah ketidakberpihakan negara dalam persoalan ini, misalnya kurangnya perlindungan hukum melalui payung Undang-Undang, atau masih berlarutnya proses penanganan hukum positif yang melibatkan kasus kekerasan terhadap perempuan. Kondisi ini diperparah dengan masih enggannya perempuan melaporkan kejadian kekerasan yang menimpa dirinya akibat adanya intimidasi, ketakutan atau yang dianggap sebagai aib keluarga (domestifikasi). Persoalan lain yang muncul adalah masih minimnya para pihak yang 
membela persoalan ini, seolah merupakan persoalan domestik. Para pegiat NGO pun masih terbatas aksesnya dalam mengadvokasi persoalan kekerasan. Hakikatnya, persoalan ini bukan hanya melibatkan aspek hulu, namun juga hilir, serta adanya campur tangan dari negara.

Kondisi lain yang bukan hanya melibatkan hukum posisitif adalah program trauma healing yang sangat dibutuhkan pasca terjadinya kasus kekerasan. Para psikolog sangat dibutuhkan, sebab yang paling penting kedua setelah kasus kekerasan ini menjadi domain hukum posistif adalah penanganan pasca kejadian. Jangan sampai justru para pelaku kekerasan dan juga korban kekerasan tidak ditangani dengan baik. Trauma psikologis yang cukup parah menyebabkan kecenderungan kekerasan akan kembali terulang di kemudian hari. Rifka Annisa membuka konseling untuk pasangan laki-laki sebagai bentuk pencegahan hadirnya kekerasan dalam rumah tangga. Pasangan (dalam hal ini, laki-laki) mendapatkan porsi yang besar dalam proses reduksi kekerasan. Karena selain sebagai partner perempuan dalam rumah tangga, kehadirannya juga berpotensi sangat besar masuk dalam pelaku kekerasan domestik. 


\section{SUPERIORITAS BUDAYA PATRIARKI}

Dalam konteks ke-Indonesia-an dengan keberadaan agama dan budaya yang memberi pengaruh satu sama lain, hal ini menciptakan dominasi laki-laki atas perempuan memperoleh legitimasi, terutama dari nilai-nilai agama yang tersosialisasi secara turuntemurun dari generasi ke generasi (Suhendi, 2011). Leege melihat keyakinan-keyakinan dan kelompokkelompok keagamaan merupakan fondasi suatu budaya. Pandangan-pandangan dunia keagamaan memberikan makna trasendental bagi dunia. Pandangan-pandangan dunia keagamaan terdiri dari nilai-nilai yang menempatkan klaim unik terhadap kebenaran serta merasionalkan hubungan sosial dan tujuan masyarakat (Leege, 2006). Geertz melihat budaya bukan sekadar sebagai wadah dari adat-adat, kegunaan-kegunaan, tradisi-tradisi, dan kebiasaan-kebiasaan, melainkan sebagai serangkaian mekanisme kontrol rencanarencana, anjuran-anjuran, aturan-aturan, intruksiintruksi untuk memandu perilaku (Leege, 2006). Pendapat Geertz dan Leege ini sebenarnya mirip dengan gagasan Roscue Pound tentang "law as tools social enginering" (Thaib dan Karmila, 1998).

Menjejak dari akar budaya dan agama tersebut, maka dapat dikatakan bahwa konstruksi sosial yang 
dibangun atas nama superioritas pria terhadap wanita, terlembaga secara inkremental, sehingga terkadang masyarakat tidak menyadari bahwa pentingnya kesetaraan gender. Hal ini kiranya bersesuaian dengan temuan Delli Carpini dan Keeter bahwa perempuan kurang mendapat informasi tentang politik daripada laki-laki, terutama di bidang isu substantif (Mendez dan Osborn, 2010), sedangkan temuan Verba, Burns, dan Schlozman pria lebih cenderung memiliki lebih banyak rasa/semangat untuk berpolitik dan berkompetisi daripada wanita sehingga masyarakat pun menjadi latah, jikalau pentas politik itu menjadi sangat maskulin dan hanya cocok untuk kalangan pria (Mendez dan Osborn, 2010). Pendapat Verba dkk ini kiranya mengamini mengapa isu-isu ketidaksetaraan gender, khususnya ketidakberdayaan perempuan dalam budaya patriaki tidak pernah menjadi topik utama yang disuarakan elit politik sehingga hal ini berdampak pada minimnya peran negara untuk mengadvokasi hak-hak perempuan atas hegemoni budaya patriaki.

Sejak masalalu, perempuan memang memiliki derajat yang direndahkan, bahkan dalam sejarah masyarakat pra Islam atau dikenal sebagai zaman Jahiliyah, disebutkan bahwa perempuan tidak lebih berharga dari suatu komoditas yang dapat dipindahtangankan atau 
diperjualbelikan dengan seenaknya (Fakih, 2006: 129). Selama berabad-abad, paradigma ini terus berkembang dalam masyarakat, bahkan warisan pemikiran itu masih dirasakan hingga saat ini. Konsep pemikiran tersebut sebenarnya telah terjebak kepada apa yang dinamakan dengan stereotip. Stereotip itu bisa disebut pemikiran keliru yang dikembangkan atas dasar konstruksi sosial dan kultural masyarakat. Stereotip merupakan pelabelan atau penandaan terhadap suatu kelompok tertentu dan stereotip ini selalu merugikan dan menimbulkan ketidakadilan (Fakih, 2006).

Konstruksi gender bukanlah hal yang kodrati sehingga dapat dipertukarkan, seperti seorang perempuan juga bisa kuat, rasional, sedangkan lakilaki dapat pula lebih emosional dan lemah. Kekeliruan mengenai gender ini, sering dipahami sebagai akibat kurangnya pemahaman tentang perbedaan antara seks (jenis kelamin) dan gender. Pengertian jenis kelamin (seks) merupakan penyifatan atau pembagian dua jenis kelamin yang ditentukan secara biologis yang melekat pada jenis kelamin tertentu. Misalnya, laki-laki adalah manusia yang memiliki penis, jakala (kalamenjing), dan memproduksi sperma. Sedangkan perempuan memiliki alat reproduksi, seperti rahim dan saluran untuk melahirkan, memproduksi telur, memiliki vagina, dan 
mempunyai alat menyusui. Artinya secara biologis atau kodrat, alat-alat tersebut tidak dapat dipertukarkan. Sedangkan gender adalah sifat yang melekat pada kaum laki-laki atau pun perempuan yang dikonstruksi secara sosial dan kultural (Fakih, 2006).

Di samping itu, Oakley dalam bukunya Sex, Gender and Society melihat gender sebagai perbedaan yang bukan biologis dan bukan kodrat dari Tuhan, namun sebuah perbedaan perilaku yang dikonstruksi secara sosial, sedangkan jenis kelamin adalah perbedaan secara biologis dan kodrat dari Tuhan (dalam Fakih, 2006). Kekeliruan menilai tentang kodrat ini telah terjadi sejak Yunani kuno. Pada saat itu, dinyatakan bahwa seorang budak dan bangsawan sudah ditentukan secara kodrat oleh Tuhan, dan akan selamanya seperti itu. Anggapan bahwa hukum kodrat adalah sama dengan hukum Tuhan dan pertentangan antara kebiasaan dan hal yang sesungguhnya telah ditakdirkan untuk hampir menjadi formula bagi kritik dari penyalahgunaan suatu hal dalammana hukum kodrat barhati-hati mucul dalam sejarah pemikiran politik kemudian hari (Sabine, 1977). hukum kodrat seolah menjadi senjata yang kuat dan melegitimasi perilaku diskriminasi, bahkan dalam bentuk kekerasan sebagai simbol superioritas kaum maskulin. 
Lemahnya pemahaman tentang seks dan gender, membuat masyarakat terjebak dalam kekeliruan definisi, bahkan ada bidang-bidang yang dikatakan bukan bidangnya perempuan atau mutlak hanya bagi laki-laki. Sempitnya pemahaman ini, membuat ruang gerak perempuan sangat terbatas, bahkan masyarakat menganggap bahwa perempuan bukanlah seorang pemimpin dan tidak layak untuk memimpin. Perempuan dianggap tidak memiliki kemampuan untuk itu. Situasi dilematis bagi kaum perempuan ini menyebabkan perempuan cenderung mengisolasi dirinya. Kondisi ini digambarkan misalnya di dunia kepemimpinan, meskipun perempuan memiliki kemampuan yang tidak kalah dengan laki-laki, tetapi mereka enggan tampil di depan, belum bisa menerima kelompoknya sendiri menjadi pemimpinnya, lebih suka rutinitas, dan cenderung menghindari tantangan dan tanggung jawab yang lebih besar. Di mata kaum laki-laki, mereka masih sering dipertanyakan dan diragukan kepemimpinannya (Susanto, 1998).

Di samping itu, adanya stereotip gender menghasilkan perbedaan dan pembagian gender yang mengakibatkan, termanifestasi dalam, posisi subordinasi kaum perempuan di hadapan laki-laki. Subordinasi ini berkaitan dengan politik, termasuk 
menyangkut soal proses pengambilan keputusan dan pengendalian kekuasaan. Subordinasi dalam bidang pengambilan keputusan dan pengendalian kekuasaan itu mengarah pada tidak adanya kepercayaan terhadap kaum perempuan. Hal ini disebabkan adanya anggapan bahwa perempuan selalu memiliki pembawaan "emosional" sehingga tidak tepat tampil sebagai pemimpin atau mengerjakan pekerjaan yang menjadi wilayah maskulin.

Kondisi ini diperparah dengan tidak adanya keberpihakan negara dalam konteks diskriminasi gender. Legitimasi negara yang juga lebih terkesan maskulin tidak mampu menganggat isu gender, spesifiknya kekerasan, traficking, pelecehan, dan seterusnya menjadi produk kebijakan. Secara konstitusi UUD 1945, warga negara memiliki hak dan kewajiban yang sama (Pasal 27, 28, 29, 30, dan 31). Namun, operasionalnya jelas kontras dan berbeda. Untuk melahirkan kepihakan penghapusan kekerasan dalam rumah tangga baru bisa muncul pada tahun 2004, melalui Undang-Undang Nomor 23 Tahun 2004. Padahal, Undang-Undang tersebut merupakan kelanjutan dari adanya UndangUndang Nomor 9 Tahun 1999 tentang Hak Asasi Manusia. Ada undang-undang yang lebih lama yang fokus pada penghapusan kekerasan pada perempuan 
melalui Undang-Undang Nomor 7 Tahun 1984, dan juga Undang-Undang Perkawinan Nomor 1 Tahun 1974. Namun secara teknis operasional, bentuk kekerasan tetap tidak dapat dicegah. Data kekinian mengenai korban kekerasan dipetakan oleh BPS sepanjang 20172019 dalam tabel berikut.

\section{Tabel 2 . Jumlah Kekerasan yang Melapor dan Mendapatkan Layanan}

\begin{tabular}{|c|c|c|c|c|c|}
\hline $\begin{array}{c}\text { Jumlah Kasus dan Persentase } \\
\text { Perempuan yang Mendapat Layanan Komprehensif }\end{array}$ \\
\hline \multicolumn{3}{|c|}{ Jumlah Kasus } & \multicolumn{4}{c|}{ Persentase } \\
\hline 2017 & 2018 & 2019 & 2017 & 2018 & 2019 \\
\hline 3.443 & 6.652 & 5.444 & $27,43 \%$ & $41,03 \%$ & $39,39 \%$ \\
\hline
\end{tabular}

Sumber: https://www.bps.go.id/indikator/indikator/view data/oooo/data/1823/sdgs 5/1

\section{KESETARAAN GENDER SEBAGAI HAK WARGA NEGARA}

Ketidaksetaraan gender juga tidak bisa dipisahkan dari hak asasi manusia, terutama hak warga negara (citizenship as rights) (Stokke, 2017) . Menurut Marshall, salah satu hak kewarganegaran yang pertama kali muncul adalah hak sipil yang terdiri dari hak-hak yang diperlukan untuk kebebasan individu-kebebasan orang, kebebasan berbicara, berpikir dan percaya, hak 
untuk memiliki properti, dan untuk menyimpulkan kontrak yang benar, dan hak atas keadilan (Marshall, 1950). Ketika berbicara demokratisasi, maka menjadi penting bagaimana proses regulasi politik menjamin perluasan hak berpartisipasi bagi orang atau kelompokkelompok yang sebelumnya dianggap tidak memiliki hak, juga tentang proses bagaimana proses politik mengakomodasi kepentingan-kepentingan kelompok yang lebih luas daripada yang telah berlaku sebelumnya, atau juga tentang proses bagaimana regulasi politik mengatur dan menjamin siapa saja orang atau pihak yang memiliki hak dan wewenang untuk berpartisipasi di dalam lembaga-lembaga negara (Pascarina et.al., 2015).

Perbedaan gender sesungguhnya tidaklah menjadi masalah sepanjang tidak melahirkan ketidaksetaraan gender. Namun yang menjadi masalah adalah konstruksi sosial yang dibangun dalam budaya patriarki dalam melihat perbedaan gender telah melahirkan berbagai ketidakadilan, khususnya bagi perempuan. Ketidakadilan gender termanifestasikan dalam pelbagai bentuk, yaitu marjinalisasi, subordinasi, stereotip, kekerasan, dan beban ganda (Susanto, 2015). Menurut Bressler, patriarki adalah sebuah sistem sosial yang menempatkan laki-laki sebagai sosok otoritas utama 
yang sentral dalam organisasi sosial. Ayah memiliki otoritas terhadap perempuan, anak-anak, dan harta benda. Secara tersirat, sistem ini melembagakan pemerintahan dan hak istimewa laki-laki dan menuntut subordinasi (Susanto, 2015). Hal ini dengan apa yang disampaikan oleh Oakley, dimana gender dikaitkan erat dengan norma-norma budaya yang berlaku dan klasifikasi sosial dari laki-laki dan perempuan dalam suatu masyarakat. dalam konsep terminologi sastra, patriaki diartikan kekuasaan seorang ayah (Elvira, 2008).

Menurut Survei Pengalaman Hidup Perempuan Nasional (SPHPN) Tahun 2016, empat faktor penyebab terjadinya kekerasan fisik dan/atau seksual terhadap perempuan yang dilakukan oleh pasangan, yaitu faktor individu, faktor pasangan, faktor sosial budaya, dan faktor ekonomi (www.kemenpppa.go.id/ 2018). Faktor individu perempuan, misalnya dari faktor pengesahan pekawinan di bawah tangan atau di luar institusi negara (nikah siri, agama, dan sebagainya), nikah di bawah umur, rentan terjadinya kekerasan. Selain itu, faktor seringnya bertengkar dengan suami atau menyerang suami atau pasangan lebih dulu rentan mendapatkan kekerasan. Faktor pasangan, tekanan ekonomi karena menganggur, suami yang memiliki kecanduan alkohol 
atau narkotika, atau memiliki pasangan lain, serta pasangan yang sering berkelahi memiliki potensi besar terjadinya kekerasan. Faktor ekonomi, dilihat dari sebab adanya kekerasan melalui rendahnya faktor ekonomi. Artinya, perempuan yang berasal dari keluarga dengan tingkat kesejahteraan yang semakin rendah memiliki risiko yang lebih tinggi untuk mengalami kekerasan fisik. Faktor sosial budaya, keluarga yang tidak diberikan nilai kesetaraan antara laki-laki dan perempuan rentan mengalami kekerasan dan tindakan diskriminatif. Di sinilah pentingnya menanamkan nilai-nilai persamaan, kesetaraan, dan keadilan gender. Selain itu, perlu adanya komitmen yang kuat dalam keluarga untuk menjalankan nilai tersebut secara konsekuen.

Melihat dari berbagai faktor yang ada itu, diharapkan negara dapat hadir dan memberikan perlindungan bagi para korban diskriminasi gender, apalagi yang sudah berwujud kekerasan. Semakin kecil komitmen negara dalam menanggulangi persoalan ini, maka kasus kekerasan sebagai bentuk supremasi patriarki dan juga diskriminasi akan terus terjadi, dengan berbagai penyebab yang telah diuraikan. Keberpihakan negara dalam isu ini juga sebagai cerminan pengayoman negara terhadap seluruh warganya yang tercermin dalam Pasal 27 UUD 1945. Selain itu, sebagai bentuk tegaknya 
supremasi hak asasi manusia tanpa membedakan jenis kelamin dan pengaruh stereotip status sosial dalam masyarakat.

\section{ADVOKASI BERBASIS GENDER}

Rifka Annisa memiliki visi mewujudkan tatanan masyarakat yang adil gender, yang tidak mentolerir kekerasan terhadap perempuan melalui prinsip keadilan sosial, kesadaran dan kepedulian, kemandirian, integritas yang baik dan memelihara kearifan lokal. Sedangkan dalam misinya, Rifka Annisa ingin mengorganisir perempuan secara khusus dan masyarakat secara umum untuk menghapuskan kekerasan terhadap perempuan dan menciptakan masyarakat yang adil gender melalui pemberdayaan perempuan korban kekerasan, termasuk di dalamnya anak-anak, lanjut usia, dan difabel, meningkatkan kesadaran dan partisipasi masyarakat melalui pendidikan kritis dan penguatan jaringan.

Rifka Annisa yang memiliki arti “Teman Perempuan” hadir karena keprihatinan yang mendalam terhadap kecenderungan budaya patriarki yang pada satu sisi memperkuat posisi laki-laki tetapi di sisi lain memperlemah posisi perempuan. Akibatnya, perempuan rentan mengalami kekerasan, baik fisik, psikis, ekonomi, 
sosial, maupun seksual seperti pelecehan dan perkosaan. Adanya persoalan kekerasan berbasis gender yang muncul di masyarakat mendorong Rifka Annisa untuk melakukan kerja dalam rangka penghapusan kekerasan terhadap perempuan. Rifka Annisa meyakini bahwa kekerasan terhadap perempuan terjadi karena adanya berbagai faktor yang saling mendukung.

Hampir keseluruhan korban tindak kekerasan yang mendapatkan advokasi dan konseling dari Rifka Annisa WCC tidak mengetahui kepada siapa mereka meminta pertolongan (lihat tabel 1). Rekomendasi mereka dapatkan melalui informasi, baik melalui sentra pelayanan kepolisian, media massa, internet, dan media sosial mengenai keberadaan Rifka Annisa. Data dari proses pencarian google indeks, Rifka Annisa masuk dalam top rank sebagai entitas civil society yang menangani persoalan kekerasan terhadap perempuan dan anak di wilayah D.I. Yogyakarta sejak tahun 1993.

Rifka Annisa menggunakan kerangka kerja ekologis (ecological framework) untuk memahami penyebab terjadinya kekerasan terhadap perempuan. Secara sederhana, kerangka kerja ekologis ini digambarkan sebagai lima lingkaran konsentris yang saling berhubungan satu dengan lainnya. Lingkaran yang paling dalam pada kerangka ekologis adalah riwayat 
biologis dan personal yang dibawa masing-masing individu ke dalam tingkah laku mereka dalam suatu hubungan. Lingkaran kedua merupakan konteks yang paling dekat, kekerasan sering kali terjadi yaitu dari keluarga atau kenalan dan hubungan dekat lainnya. Lingkaran ketiga, institusi dan struktur sosial, baik formal maupun informal, dengan hubungan tertanam dalam bentuk pertetanggaan, di tempat kerja, jaringan sosial, dan kelompok kemitraan. Lingkaran keempat, lingkungan ekonomi dan sosial, termasuk norma-norma budaya dan sistem hukum negara. Sedangkan lingkaran paling luar adalah lingkungan ekonomi dan sosial global, institusi dan struktur sosial global, jaringan global dan kelompok kemitraan bilateral atau global (www.rifkaannisa.org).

Kerangka kerja ekologis tersebut yang menjadi landasan gerakan Rifka Annisa dalam upaya menghapuskan kekerasan terhadap perempuan dan mewujudkan tatanan sosial yang berkeadilan sosial gender (social-gender justice). Program-program Rifka Annisa dimaksudkan untuk melakukan intervensi pada setiap penyebab kekerasan terhadap perempuan serta ketidakadilan sosial-gender sebagaimana digambarkan oleh lima lingkaran konsentris dalam kerangka kerja 
ekologis tersebut, yaitu pada level individu, keluarga, komunitas hingga negara, dan struktur global.

Rifka Annisa menyadari bahwa ketidakadilan dan ketidaksetaraan gender serta kekerasan terhadap perempuan merupakan persoalan sosial yang dihadapi oleh perempuan dan sekaligus laki-laki. Keduanya sama-sama tidak diuntungkan oleh situasi tersebut. Dalam sistem budaya patriarki, laki-laki akan lebih rentan menjadi pelaku, sedangkan perempuan rentan menjadi korban. Karenanya, keadilan dan kesetaraan gender tidak bisa diwujudkan hanya dengan melibatkan perempuan. Pendekatan pemberdayaan yang berfokus pada perempuan saja terbukti kurang efektif manakala tidak ada dukungan dari laki-laki, baik pada level keluarga, lingkungan, maupun masyarakat secara lebih luas. Keadilan dan kesetaraan gender baru mungkin terjadi bila perempuan dan laki-laki bekerja sama untuk mewujudkan perubahan, yaitu laki-laki dan perempuan saling menguatkan, menghargai, dan menghormati. Program-program dan kegiatan Rifka Annisa didesain berdasarkan perspektif ini, agar laki-laki dan perempuan saling bekerja sama mewujudkan tatanan sosial yang berkeadilan sosial gender tanpa kekerasan terhadap perempuan. 
Advokasi anti kekerasan terhadap perempuan memerlukan pemaknaan yang lebih luas, yaitu advokasi yang tidak saja bisa menjangkau persoalan mendasar tetapi juga dapat menjadi bagian dari proses pemulihan. Advokasi ini tidak saja meliputi penanganan sebelum dan selama proses, tetapi juga meliputi pasca advokasi. Titik tekan dari advokasi ini terletak pada perempuan korban kekerasan sebagai subjek. Dengan pendekatan ini, korban kekerasan tidak saja mendapatkan penanganan pemulihan secara umum dan menjadi objek advokasi. Tetapi lebih dari itu, korban dapat mengenali persoalan yang dialami dan mempunyai kesadaran untuk berdaya. Pada titik inilah, advokasi kekerasan terhadap perempuan akan bekerja secara utuh karena menjadikan prosesnya sebagai bagian dari pemulihan korban (Myra dkk, 2018).

Bagaimana pun proses yang lebih penting adalah konsep advokasi. Bukan hanya secara aspek legal, namun konsep advokasi secara keseluruhan. Dalam hal ini, ada tiga cermin dalam memantau proses advokasi, di antaranya pertama, advokasi hulu. Prinsip yang diterapkan pada advokasi hulu adalah mencoba untuk memasukkan poin kekerasan yang pada awalnya bersifat domestik menjadi persoalan publik, yang masuk dalam delik pidana umum. Masuknya pasal atau peraturan 
yang mengikat secara yuridis terkait dengan kekerasan domestik ini mendorong semakin menurunnya praktik kekerasan terhadap perempuan di ranah domestik. Kedua adalah proses advokasi psikologis (trauma healing). Proses ini melibatkan penanganan medis konseling, dalam melibatkan fisioterapis maupun psikiater yang memang berpengalaman dalam menangani pasien yang memiliki trauma tingkat tinggi (berat).

Kondisi pemulihan trauma psikologis ini memberikan makna positif dalam menciptakan kestabilan secara emosional bagi korban kekerasan. Para perempuan yang mendapatkan konseling sangat membutuhkan para pihak yang dipercaya sebagai perantara dalam mengatasi persoalannya. Dalam hal ini, tidak sembarang orang mampu memberikan trauma healing sehingga memang dituntut para profesional yang ahli dalam bidangnya. Ketiga, advokasi hilir (supremacy of law). Advokasi hilir bermakna hadirnya keadilan hukum yang seimbang bagi pelaku tindak kekerasan. Pada awalnya, kekerasan yang dianggap sebagai produk domestik harus dikembalikan pada konsep pidana hukum umum. Dengan demikian, para pelaku yang memang telah melakukan tindakan kekerasan dianggap sebagai penjahat yang wajib dihukum. Persoalan yang muncul 
selajutnya adalah bagaimana si perempuan yang merupakan pasangannya menerima perlakuan dan juga putusan hukum seandainya pasangannya mendapatkan hukum yang setimpal? Pertanyaan inilah yang muncul sebagai kelanjutan dari advokasi. Pemahaman dari adanya konseling dan kerja sama pasangan perempuan dalam proses reduksi kekerasan menjadi sangat vital. Kerja sama bersama atas persoalan ini akan sedikit banyak berpengaruh terhadap perlakuan kekerasan yang ada dan mewujudkan langkah kolaborasi positif bagi kasus ini.

\section{LEMAHNYA PERLINDUNGAN NEGARA}

Secara tekstual, negara sebanarnya telah mencoba hadir dalam mengatasi persoalan ini. Ketidaksetaraan gender yang bermuara pada kekerasan dianggap sebagai residu dari lemahnya kehadiran negara. Sebagai pihak yang berwenang untuk mengatur dan memaksa, negara memosisikan diri pada pihak yang sangat pasif. Rata-rata korban yang mendapatkan pendampingan (konseling dan bantuan hukum) dari Rifka Annisa sama sekali tidak mengetahui ke mana dan pada siapa mereka meminta bantuan. Selain itu, mereka juga tidak mengetahui bahwa kasus kekerasan dan tindakan diskriminatif berbias gender merupakan pelanggaran terhadap Undang- 
Undang. Langkah konkrit negara dalam persoalan ini misalnya dengan membuat Undang-Undang Nomor 21 Tahun 2017 tentang Trafficking (perdagangan manusia). Sementara itu dalam konteks lokal, Provinsi D.I. Yogyakarta telah membuat Peraturan Daerah (Perda) Nomor 3 Tahun 2012 tentang Perlindungan Perempuan terhadap Kekerasan. Meskipun Perda ini telah hadir sebagai bentuk representasi negara, namun dalam proses pelaksanaannya masih banyak kasus yang terjadi (lihat tabel 2). Kecenderungan kekerasan muncul dengan tren yang semakin meningkat, padahal payung hukum dan ancaman pidana telah ada.

Hal yang penting dari persoalan ini kemudian dipetakan oleh Rifka sebagai bentuk konstruksi sosial dalam masyarakat. Sejatinya, kekerasan tidak dapat hilang dalam proses yang formal, tetapi harus melibatkan diri dalam informality, misalnya memberikan edukasi, konseling, membuka wawasan berbasis gender, sampai pada pembukaan ruang dialog publik untuk mendorong hadirnya penyadaran pada masyarakat. Hal inilah yang luput dari perhatian pemerintah. Pendekatan yang bersifat institusional formal sangat tidak sesuai untuk mengatasi persoalan kekerasan dan trafficking ini. Selain itu, rujukan yang mayoritas diterima oleh korban kekerasan justru merekomendasikan pada Rifka sebagai 
civil society. Padahal sejatinya, persoalan ini menjadi persoalan publik yang membutuhkan campur tangan negara secara konkrit.

Proses pengawasan dan penegakan aturan mungkin menjadi instrumen kunci dalam mengatasi persoalan ini. Dalam konteks tersebut, Rifka telah mendorong seluruh pemerintah Daerah Kabupaten/Kota se-Yogyakarta untuk membentuk Woman Crisis Centre (WCC) sebagai tempat untuk menampung urusan kekerasan ini. Dalam aspek operasional, WCC bentukan pemerintah daerah melibatkan banyak instansi (dinas), misalnya Dinas Pemberdayaan Perempuan dan Anak, Dinas Tenaga Kerja, Dinas Kesehatan, Dinas Sosial, dan sebagainya. Pola kolaboratif inilah yang kemudian memunculkan perspektif kebijakan yang berbasis gender. Namun sayangnya, hal tersebut baru dapat diwujudkan pada tahun 2013 pasca Perda Nomor 3 Tahun 2012 disahkan oleh Pemerintah Provinsi DIY. Jika dicermati, dari mulai kasus kekerasan ini muncul sampai dengan tahun 2012, negara dianggap nihil dalam persoalan ini.

Instansi lain yang terlibat misalnya kepolisian, juga cenderung menempatkan korban sebagai pihak yang seolah bersalah. Interogasi yang digunakan, disamakan dengan tata cara mendapatkan Berita Acara Pemeriksaan (BAP) kasus kriminal biasa. Padahal 
dalam konteks korban, pendekatan psikologis dan humanis sangat dibutuhkan. Mereka para korban adalah pihak yang sangat tertekan secara psikis sehingga dibutuhkan psikiater untuk mendampingi dalam proses pemberkasan kasus. Masih gagapnya negara dalam mengatasi persoalan ini, merupakan cermin bahwa kehadiran negara dengan alat kekuasaannya sama sekali belum sepenuhnya berperspektif gender. Padahal dalam kerangka konseptual, pelibatan civil society adalah sebagai penyalur aspirasi dan bukan penyelesai persoalan publik. Namun, dengan melihat Rifka Annisa ini seolah entitas civil society yang mendominasi dalam proses penyelesaian dan pencegahan kekerasan dan dsikriminasi gender yang terjadi dalam masyarakat.

\section{KESIMPULAN}

Dari uraian mengenai persoalan gender dalam konteks perspektif korban dengan melihat studi kasus yang ada pada entitas civil society Rifka Annisa WCC, terlihat bahwa kekerasan terhadap perempuan merupakan perbuatan yang melibatkan persoalan domestik sebagai proses hadirnya budaya patriarki dalam masyarakat. Kecenderungan patriarki ini menjadi 
faktor utama yang memunculkan bias gender, bukan hanya dalam lingkungan domestik, namun sampai pada konstruksi sosial masyarakat dan bahkan negara. Kehadiran NGO Rifka Annisa merupakan sebuah solusi atas keadaan yang bersifat kuldesak, dimana masih sedikit sekali NGO yang memang berkonsentrasi dalam mengatasi persoalan kekerasan terhadap perempuan.

Kontribusi Rifka Annisa WCC bukan hanya pada aspek penanggulangan, namun telah masuk dalam proses memengaruhi kebijakan pemerintah dan juga melakukan aksi pendampingan secara psikologis serta pendampingan hukum. Persoalan kekerasan mesti diatasi dengan melibatkan tiga segmen sekaligus, yaitu isu hulu yang berpangkal pada aspek yuridis UndangUndang; Hal yang berpangkal pada pendampingan secara psikologis atau trauma healing bagi korban kekerasan; Program hilir yang mewujud berupa penanganan secara hukum positif, dimana kekerasan domestik dipandang sebagai hal yang tidak kebal hukum. Dalam konteks diskriminasi gender, perspektif korban terhadap institusi negara dipandang masih sangat minim. Negara memang mengeluarkan kebijakan dengan produk hukum, baik berupa Undang-Undang dan turunannya. Namun faktanya, hadirnya Undang-Undang tidak disertai dengan langkah pengawasan dan implementasi 
yang baik. Kecenderungan ini muncul dengan masih banyaknya kasus pasca aturan perlindungan hadir sebagai hukum positif.

Diskriminasi dalam perspektif gender merupakan persoalan kultural sehingga proses penyelesaiannya harus dilakukan oleh aktor negara dan civil socety secara informality, melalui edukasi, konseling, pembukaan ruang publik dan sebagainya. Informality ini bertujuan untuk menghapus praktik patriarki dalam masyarakat. Selain itu, telah terbukti bahwa proses pendekatan legalistik dengan kekuatan negara tidak mampu menangani persoalan gender dari akarnya.

Perlu keterlibatan berbagai stakeholder (pemerintah, civil society) dan juga masyarakat secara umum dalam mengatasi persoalan diskriminasi gender. Dukungan berbagai pihak ini merupakan penegasan bahwa diskriminasi tidak dapat dibenarkan dalam alam demokrasi, dan sesuai dengan stereotip gender yang disampaikan oleh Fakih (2006), maka persoalan utama adalah cara pandang (mind set). Perubahan mind set menjadi kunci hadirnya kesetaraan dalam masyarakat, bahkan institusi negara.

Dalam perspektif korban, diskriminasi gender juga akibat ketidaktahuan. Korban yang mendapatkan 
perlakuan diskriminatif cenderung tidak mengetahui bahwa itu adalah persoalan publik. Domestifikasi persoalan kekerasan dan bias gender dalam masyarakat membuat kasus seperti ini sulit diungkap dan diatasi dengan baik. Pola pendekatan dan sosialisasi sangat penting sebagai instrumen untuk mengatasinya. 


\section{REFERENSI}

Amalia, Mia. (2011). Kekerasan Perempuan dalam Perspektif Hukum dan Sosiokultural. Jurnal Wawasan Hukum, Vol. 25 No. 02, September 2011. https://core.ac.uk/ download/pdf/287307563.pdf.

Bungin, Burhan. (2007). Penelitian Kualitatif. Jakarta: Kencana.

Diarsi, Myra, dkk. (2018). Layanan Terpadu: Pertautan Multi Disiplin dan Sinergi Kekuatan Masyarakat dan Negara, Komnas Perempuan, September 2005. Dalam Laporan Data Advokasi Kekerasan terhadap Perempuan.

Elfira, Mina. (2008). Vasilisa Maligina Karya A.M. Kollontai: Sebuah Rekonstruksi atas Konsep Maskulinitas Rusia. Wacana: Jurnal Ilmu Pengetahuan Budaya Universitas Indonesia, Vol. 10 No. 1, 1 April 2008.

Fakih, Mansur. (2006). Analisis Gender dan Transformasi Sosial. Yogyakarta: Pustaka Pelajar.

Leege, David C. \& Kellstedt, Lyman A. (2006). Agama dalam Politik di Amerika. Terjemahan dari buku: Rediscovering the Relegious Factor in American Politics. Penerjemah: Debbie A. Lubis \& A. Zaim Rofiqi. Bandung: Mizan. 
Marshall, T. H. (1950). Citizentship and Social Class, and Other Essays. United Kingdom: Syndics Of Cambridge University Press.

Mendez, Jeanette Morehouse and Osborn, Tracy. (2010). Gender and the Perception of Knowledge in Political Discussion: Political Research Quarterly, Vol. 63, No. 2 (June 2010), pp. 269-279. Published: Sage Publications, Inc. on behalf of the University of Utah Stable. http://www.jstor.org/stable/20721489.

Nazir. Moch, (2009). Metode Penelitian. Jakarta: Ghalia Indonesia.

Paskarina, Caroline et.al. (2015). Berebut Kontrol atas Kesejahteraan: Kasus-kasus Politisasi Demokrasi di Tingkat Lokal. UGM: PolGov.

Sabine, G.H. (1977). Teori-Teori politik Sejarah dan Perkembangannya. Jakarta: Bina Cipta.

Suhendi, Didi. (2011). Pergeseran Visi Pendidikan Perempuan dalam Kesejarahan Novel-Novel Indonesia. Kajian Kritik Sastra Feminis. http:// eprints.unsri.ac.id/3954/2/Isi.pdf.

Susanto, Nanang Hasan. (2015). Tantangan Mewujudkan Kesetaraan Gender dalam Budaya Patriaki. Jurnal Muwazah, Volume 7, Nomor 2, Desember 2015. 
Stokke, Kristian. (2013). Conceptualizing the Politics of Citizenship. Department of Sociology and Human Geography, University of Oslo.

https://www.researchgate.net/publication/260599279_ Conceptualizing_the_Politics_of_Citizenship.

Thaib, Dahlan \& Adi, Mila Karmila. (1998). Hukum dan Kekuasaan. Fakultas Hukum UII.

\section{MEDIA DARING:}

Profile Komisi Nasional Perempuan. https://www. komnasperempuan.go.id/about-profile-komnasperempuan.

Sejarah Rifka Annisa. http://www.rifka-annisa.org/ id/2013-10-04-07-06-57/sejarah.

Perempuan Rentan Jadi Korban KDRT, Kenali Faktor Penyebabnya https://www.kemenpppa. go.id/index.php/page/read/31/1742/ perempuan-rentan-jadi-korban-kdrt-kenalifaktorpenyebabnya\#: : :text=Berdasarkan\%2O hasil\% 2OSPHPN\%2OTahun\%202016,sosial\%2O budaya\%2C\%2odan\%2ofaktor\%2oekonom. 
Peraturan Daerah Provinsi D.I. Yogyakarta. Nomor 3 Tahun 2012 Tentang Perlindungan Perempuan dan Anak Korban Kekerasan. https://www.bphn.go.id/data/ documents/perda3-2012.pdf.

Profile Komisi Nasional Perempuan. https://www. komnasperempuan.go.id/about-profile-komnasperempuan.

Sejarah Rifka Annisa. http://www.rifka-annisa.org/ id/2013-10-04-07-06-57/sejarah.

Divisi dan Program Rifka Annisa. http://www.rifka-annisa. org/id/2013-10-04-07-06-57/divisi-dan-program. 